\title{
トール油の不均化反応
}

\author{
石上雅久・有本邦夫・井上良計・藤井亮一・山根耕治 \\ 播磨化成工業株式会社（加古川市野口町水足 671-4)
}

\section{Disproportionation of Tall Oil}

\author{
Ma:ahisa Ishigami, Kunio Arimoto, Yoshikazu Inoue, Ryōichi FujiI and Kōji Yamane \\ Harimakaseikogyo Co., Ltd. (671-4 Mizuashi, Noguchichō, Kakogawa)
}

\begin{abstract}
Disproportionation of tall oil with several catalysts was studied. Iodine and hydrogen iodide were excellent catalysts, and the optimum result was obtained when tall oil was heated with $0.5 \%$ iodine for 4 hours at $220 \sim 240^{\circ} \mathrm{C}$.

In this reaction, the transfer of hydrogen from abietic acid to linolic acid was observed, and the product mainly contained dehydroabietic acid and octadecenoic acid.

It was suggested that the octadecenoic acid formed from linolic acid through the conjugated linolic acid, because the conjugated linolic acid was observed in early stage, and the double bond in the octadecenoic acid distributed widely from $\mathrm{C}-5$ to $\mathrm{C}-14$.
\end{abstract}

\section{1 緒 言}

ロジンの不䚷化反応については，すでに多くの報告が なさ社ており, 不均化の触媒としては, 水素添加触媒で ある， $\mathrm{Ni} ＼textrm{P d}$ および Pt などが，また脱水素触媒であ るイオウ，セレンおよびヨウ素などがよく知られてい る。また不均化口ジンはすでに工業的規模での生産が行 われており，合成ゴムの乳化剂として大量に使用されて いる。現在合成ゴムのうちその主流をなしているのは乳 化重合 S.B.R. であり，こ机の製造にあたっては乳化剂 として前記不均化ロジンが使用されているが同時にほぼ 同量の脂肪酸 (牛脂脂肪酸を微水添したもの) を混合し て使用する場合が多く, S.B.R. \#1502 タイプがこれで S.B.R. 全生産量の約 $2 / 3$ を占めている。

一方トール油はその産地により組成に多少の変動はあ るが，ナレイン酸，リノール酸を主成分とする脂肪酸と アビエチン酸を主成分とする樹脂酸のほぼ等量混合物で ある。しかしリノール酸1) およびアビエチン酸2)のよう な共役ジエン構造を有する樹脂酸は， S.B.R. の乳化重 合にあたり，その重合を阻害することが知られており， トール油注そのままでは合成ゴムの乳化剤として使用す るこ之ができない。トール油中のこれら重合阻害物質を 一挙に乳化重合用乳化剂にかえることができればその工 業的価値洼きわめて大きいものといえる。

トール油の不均化については, 前記触媒のうち, $\mathrm{Ni}^{33}$, $\mathrm{SO}_{2}{ }^{4}$ ， ヨウ素(),6) による不均化についての 報告がある が，いずれも特許であり，その反応の詳細については報
告されていない。

著者らは, トール油の不均化による合成ゴム乳化剤の 工業的生産を目的とし触媒の種類および反応条件につい て詳細な検討を加え，二三の知見を得たので報告する。

\section{2 実験}

\section{$2 \cdot 1$ 原料}

トール油はアメリカ南部で産出されたものを, 減圧下 で蒸留（bp 185 240 $\mathrm{C} / 2 \mathrm{mmHg}$ ) し, 初留および不揮 発成分を除去したもので酸価 174, ケン化価 179 , 脂肪 酸 $50.9 \%$, 樹脂酸 $39.9 \%$, 不ケン化物 $9.2 \%$ を含有 するもの（以下蒸留トール油という）を使用した。なお ガスクロマトグラフィー（以下 GLC 法という）による 組成を Table-1 に示す。

触媒として使用した Ni-ケイソウ土は日揮化学社製の 安定化ニッケル，N-103 (Ni 50〜52\%) を，Pd-活性炭 (Pd 5\%)，および Rh-活性炭（Rh 5\%）は日本エンゲ

Table-1 Composition of distilled tall oil.

\begin{tabular}{l|c}
\hline \multicolumn{1}{c|}{ Component } & Content (\%) \\
\hline Palmitic acid & 3.8 \\
Oleic acid & 23.3 \\
Linolic acid & 19.6 \\
Other fatty acid & 4.2 \\
Abietic acid & 17.6 \\
Dehydroabietic acid & 8.1 \\
Other resin acid & 14.2 \\
\hline
\end{tabular}


ルハルト社製のものを使用した。ヨウ素，ヨウ化水素酸

(47\% 水溶液)，イオウおよびセレン注市販試薬特級を そのまま使用した。

\section{$2 \cdot 2$ 反応操作}

蒸留トール油 $300 \mathrm{~g}$ を温度計, 冷却管および窒素ガ ス吹き込み管, かきまぜ器を取り付けた, 四つロフラス コにとり, 窒素ガスを吹き込みながら所定温度まで昇温 したのち, 所定量の触媒を加え, 所定時間反応させ, サ ンプリングを行った。

\section{$2 \cdot 3$ 分析方法}

\section{$2 \cdot 3 \cdot 1$ ガスクロマトグラフィー}

試料はエーテルに溶解し, ジアジメタンにより常法に したがいメチルエステル化し, エーテルを留去して GLC 用分析試料とした。GLC は柳本 G-8 に水素炎 イオン化検出器を用い, 次の条件で測定した。カラム： DEGS $\{10 \%$ on chromosorb W $(60 \sim 80 \mathrm{mesh}), 4 \mathrm{~mm} \phi$ $\times 2.25 \mathrm{~m}\}$, カラム温度 $175 \sim 210^{\circ} \mathrm{C}$ で $2^{\circ} \mathrm{C} / \mathrm{min}$ の割合 で昇温, 注入口温度 $275^{\circ} \mathrm{C}$ 。

各成分はトール油中に含まれるパルミチン酸 $(3.8 \%)$ を内部標準として武田理研製のデジタルインテグレータ 一による各ピークの積分比より算出した。

$2 \cdot 3 \cdot 2$ trans -脂肪酸の定量

試料約 $1 \mathrm{~g}$ を採取し，不ケン化物測定法 (ASTM, D-803）にしたがい不ケン化物を除去したのち，水層を 希硫酸で酸性にし, 油層をエーテルで抽出する。エーテ ル層は水洗, 脱水 (無水ボウ硝), 濃縮したのちメチル 硫酸試液 (濃硫酸 $5 \mathrm{~m} l$ をメタノール $1000 \mathrm{~m} l$ に加え $1 \mathrm{hr}$ 募沸したもの) $20 \mathrm{~m} l$ を加え $10 \mathrm{~min}$ 加熱還流し, 脂肪酸だけをメチル化する。分液漏斗に移し, エーテル $100 \mathrm{~m} l$ を加え, $0.5 \% \mathrm{KOH}$ 水溶液 $50 \mathrm{~m} l$ で 2 回抽出 乙樹脂酸をのぞく。エーテル層は, 水洗, 脱水し（無水 ボウ硝）エーテルを留去した後, 日立赤外分光器 EPIG 3 を使用して, AOCS 法?)にしたがって trans-脂肪 酸の含有量を求めた。

$2 \cdot 3 \cdot 3$ 二重結合位置の決定

$2 \cdot 3 \cdot 2$ と同様にして得られた脂肪酸メチルエステルを 椎名らの方法 ${ }^{8)}$ によりオン゙ン酸化分解をし, 得られた一 塩基酸, 二塩基酸をジアゾメタンでメチルエステル化し た。

メチルエステルは 2.3.1 と同様に柳本 G-8 に水素 炎イオン化検出器を用い, 次の測定条件で GLC を行 い，一塩基酸メチルの各ピークの積分比より二重結合位 置の分布を求めた。カラム: DEGS $\{10 \%$ on chromosorb $\mathrm{W}$ (60 $80 \mathrm{mesh}) 4 \mathrm{~mm} \phi \times 2.25 \mathrm{~m}\}$ カラム温度 $100 \sim$ $200^{\circ} \mathrm{C}$ で $6^{\circ} \mathrm{C} / \mathrm{min}$ の割合で昇温, 注入口温度 $275^{\circ} \mathrm{C}$ 。 $2 \cdot 3 \cdot 4$ その他

酸価およびケン化価は基準油脂分析法により，樹脂酸 含有量は ASTM D-1240により, 不ケン化物含有量は
ASTM D-803 により測定し， $\{100$-(樹脂酸含有量十 不ケン化物含有量) \}をもって脂肪酸含有量とした。

\section{3 実験結果および考察}

\section{1 触媒の種類の検討}

まず蒸留トール油を原料とする不均化反応に攻代す各 種触媒の効果を比較検討した。反応条件および結果を Table-2 に示す。

トール油中にはパルミチン酸, オレイン酸, リノール 酸, アビエチン酸, デヒドロアビエチン酸のほかに少量 のステアリン酸, 共役リノール酸, アラキジン酸, ベへ ン酸などの脂肪酸およびパラストリン酸, ネオアビェチ ン酸, ピマール酸, イソピマール酸などの樹脂酸の異性 体が含まれているが本実験ではこれら少量含有量につい ては測定しなかった。

Table-2 にみられるように，Niーケイソウ土を $5 \%$ 使用した $270^{\circ} \mathrm{C}$ の反応では樹脂酸についてはデヒドロ アビエチン酸が相当量生成しており, 脂肪酸については リノール酸が顕著に減少しているがオクタデセン酸含量 はほ上んど変化がみられず，リノール酸の重合が起こ。 ているものと考えられる。 $220^{\circ} \mathrm{C}$ においても同样の傾向 がみられるが反応はあまり進行していない。

$\mathrm{Pd}$-活性炭を $5 \%$ 使用した反応では $270^{\circ} \mathrm{C} 1 \mathrm{hr}$ で アビェチン酸含量はすでに0になっており， Niーケイソ ウ土に比べて反応は速く, デヒドロアビェチン酸の生成 率も非常に良い結果を示している。またりノール酸の大 幅な減少のほかに, オクタデセン酸のいくらかの増加が みられる。Rh-活性炭による反応ではリノール酸, アビ エチン酸の減少はみられるがデヒドロアビエチン酸の増 加はあまり認められない。

ヨウ素を $1 \%$ 使用した反応では $220^{\circ} \mathrm{C} 1 \mathrm{hr}$ ですでに リノール酸, アビエチン酸は全く認められず，モノェン 酸, デヒドロアビエチン酸の生成がきわめて顕著であ る。ヨウ化水素酸についてもほぼ同様の結果が得られて いる。

イオウあるいはセレンを使用した反応ではリノール 酸, アビエチン酸は減少し, デヒドロアビエチン酸は増 加の傾向にあるがオクタデセン酸についてはほとんど変 化していない。

以上トール油を各種触媒を用いて高温で反态させる と, 樹脂酸だけでなく, 脂肪酸にも変化が認められ, 特 にヨウ素およびヨウ化水素酸を触媒として使用するとき は短時間のらちにリノール酸のオクタデセン酸への変化 がみられ, オクタデセン酸のリノール酸に対する収率 は $65 \%$ ，またデヒドロアビエチン酸のアビエチン酸に 対する収率は $75 \%$ に達する。

このようにヨウ素またはヨウ化水素酸を触媒上してト ール油を加熱する上きアビエチン酸とリノール酸の間に 
Table-2 Disproportionation of tall oil with several catalysts.

\begin{tabular}{|c|c|c|c|c|c|c|c|c|c|}
\hline & \multicolumn{2}{|c|}{ Catalyst } & \multirow{2}{*}{$\begin{array}{l}\text { Temp. } \\
\left({ }^{\circ} \mathrm{C}\right)\end{array}$} & \multirow{2}{*}{$\begin{array}{c}\text { Time. } \\
\text { (hr) }\end{array}$} & \multirow{2}{*}{$\begin{array}{l}\text { Pal. } \\
(\%)\end{array}$} & \multirow{2}{*}{$\begin{array}{l}\text { Oct. } \\
(\%)\end{array}$} & \multirow{2}{*}{$\begin{array}{l}\text { Lin. } \\
(\%)\end{array}$} & \multirow{2}{*}{$\begin{array}{l}\text { Ab. } \\
(\%)\end{array}$} & \multirow{2}{*}{$\begin{array}{l}\text { Deab } \\
(\%)\end{array}$} \\
\hline & & $(\%)$ & & & & & & & \\
\hline & & & & 0 & 3.8 & 23.3 & 19.6 & 17.6 & 8.1 \\
\hline 1 & $\begin{array}{c}\mathrm{Ni} / \mathrm{Kiese} \\
\text { lguhr }\end{array}$ & 5 & 270 & $\begin{array}{l}1 \\
2 \\
4\end{array}$ & " & $\begin{array}{l}24.7 \\
26.6 \\
24.6\end{array}$ & $\begin{array}{l}4.4 \\
2.3 \\
2.3\end{array}$ & $\begin{array}{l}0.7 \\
0 \\
0\end{array}$ & $\begin{array}{l}17.8 \\
17.8 \\
16.8\end{array}$ \\
\hline 2 & $\begin{array}{c}\mathrm{Ni} / \mathrm{Kiese} \\
\text { lguhr }\end{array}$ & 5 & 220 & $\begin{array}{l}1 \\
2 \\
4\end{array}$ & " & $\begin{array}{l}23.6 \\
24.0 \\
25.7\end{array}$ & $\begin{array}{r}17.8 \\
15.6 \\
9.9\end{array}$ & $\begin{array}{l}12.2 \\
10.2 \\
10.4\end{array}$ & $\begin{array}{l}8.4 \\
8.8 \\
9.1\end{array}$ \\
\hline 3 & $\mathrm{Pd} / \mathrm{C}$ & 3 & 270 & $\begin{array}{l}1 \\
2 \\
4\end{array}$ & "' & $\begin{array}{l}31.7 \\
30.6 \\
27.5\end{array}$ & $\begin{array}{l}2.9 \\
2.5 \\
0\end{array}$ & $\begin{array}{l}0 \\
0 \\
0\end{array}$ & $\begin{array}{l}24.3 \\
23.9 \\
23.0\end{array}$ \\
\hline 4 & $\mathrm{Pd} / \mathrm{C}$ & 3 & 220 & $\begin{array}{l}1 \\
2 \\
4\end{array}$ & " & $\begin{array}{l}25.1 \\
25.2 \\
27.0\end{array}$ & $\begin{array}{r}15.1 \\
23.2 \\
7.1\end{array}$ & $\begin{array}{r}11.2 \\
10.7 \\
8.0\end{array}$ & $\begin{array}{r}8.4 \\
10.0 \\
14.7\end{array}$ \\
\hline 5 & $\mathrm{Rh} / \mathrm{C}$ & 2 & 270 & $\begin{array}{l}1 \\
2 \\
4\end{array}$ & " & $\begin{array}{l}22.7 \\
22.3 \\
22.0\end{array}$ & $\begin{array}{r}11.8 \\
9.4 \\
6.0\end{array}$ & $\begin{array}{l}6.6 \\
5.4 \\
3.7\end{array}$ & $\begin{array}{r}9.7 \\
9.8 \\
11.1\end{array}$ \\
\hline 6 & Iodine & 1 & 220 & $\begin{array}{l}1 \\
2 \\
4\end{array}$ & " & $\begin{array}{l}36.0 \\
36.1 \\
36.0\end{array}$ & $\begin{array}{l}0 \\
0 \\
0\end{array}$ & $\begin{array}{l}0 \\
0 \\
0\end{array}$ & $\begin{array}{l}20.8 \\
20.2 \\
20.7\end{array}$ \\
\hline 7 & Iodine & 1 & 200 & $\begin{array}{l}1 \\
2 \\
4\end{array}$ & $\begin{array}{l}" \prime \\
" \prime\end{array}$ & $\begin{array}{l}30.8 \\
30.9 \\
34.8\end{array}$ & $\begin{array}{l}3.4 \\
1.4 \\
0\end{array}$ & $\begin{array}{l}0 \\
0 \\
0\end{array}$ & $\begin{array}{l}20.3 \\
20.4 \\
21.5\end{array}$ \\
\hline 8 & $\begin{array}{l}\text { Hydroiodic } \\
\text { acid }\end{array}$ & 2 & 220 & $\begin{array}{l}1 \\
2 \\
4\end{array}$ & " & $\begin{array}{l}33.4 \\
32.3 \\
34.1\end{array}$ & $\begin{array}{l}0 \\
0 \\
0\end{array}$ & $\begin{array}{l}0 \\
0 \\
0\end{array}$ & $\begin{array}{l}20.5 \\
18.2 \\
19.0\end{array}$ \\
\hline 9 & Sulfur & 1 & 270 & $\begin{array}{l}1 \\
2 \\
4\end{array}$ & " & $\begin{array}{l}23.3 \\
22.6 \\
23.4\end{array}$ & $\begin{array}{l}15.0 \\
13.4 \\
12.4\end{array}$ & $\begin{array}{l}8.6 \\
5.3 \\
4.3\end{array}$ & $\begin{array}{l}17.3 \\
16.4 \\
17.3\end{array}$ \\
\hline 10 & Sulfur & 1 & 220 & $\begin{array}{l}1 \\
2 \\
4\end{array}$ & " & $\begin{array}{l}22.8 \\
23.4 \\
23.4\end{array}$ & $\begin{array}{l}15.0 \\
15.2 \\
14.5\end{array}$ & $\begin{array}{r}14.9 \\
10.2 \\
9.1\end{array}$ & $\begin{array}{l}12.3 \\
15.3 \\
16.2\end{array}$ \\
\hline 11 & Selenium & 0.5 & 270 & $\begin{array}{l}1 \\
2 \\
4\end{array}$ & " & $\begin{array}{l}23.0 \\
23.5 \\
23.1\end{array}$ & $\begin{array}{l}18.2 \\
15.9 \\
13.0\end{array}$ & $\begin{array}{r}12.7 \\
8.2 \\
3.8\end{array}$ & $\begin{array}{l}11.5 \\
13.7 \\
17.7\end{array}$ \\
\hline
\end{tabular}

Pal. Palmitic acid, Oct. Octadecenoic acid, Lin. Linolic acid Ab. Abietic acid, Deab. Dehydroabietic acid,

比較的好収率で水素の移動が起こり不均化することは注 目される。

トール油を $1 \%$ のヨウ素とともに $220^{\circ} \mathrm{C}$ で $4 \mathrm{hr}$ 加 熱したもののガスクロマトグラムを原料の蒸留トール油 とともに Fig.-1 に示す。

このようにして得られるものは主としてモノエン酸と デヒドロアビエチン酸からなる混合物でありそのままで 合成ゴム製造時の乳化剈として使用が可能である。

\section{2 ヨウ素触媒によるトール油の不均化}

3.1 においてトール油の不均化触媒としてヨウ素が非 常にすぐれていることが確認できたのでその反応条件に ついて詳細な検討を行った。

\section{$3 \cdot 2 \cdot 1$ 酸価およびロジン含有量の変化}

温度および触媒添加量を変え $4 \mathrm{hr}$ 反応させたときの 生成物の酸価を Fig.-2 に示す。

温度が高いほど, 触媒添加量が大きいほど酸価の低下
が大きくなっている。 $220^{\circ} \mathrm{C}$ まで は酸価の低下はそれほど大きくな いが, $240^{\circ} \mathrm{C}$ では極端に酸価が低 下している。

また低温では反応の初期に一時 的に酸価の上昇が認められたが， これは反応中ヨウ化水素の生成を 示唆しているものと考える。

$240^{\circ} \mathrm{C} ， 4 \mathrm{hr}$ の反応条件で触媒 添加量を変化させた場合の酸価お よび生成物中の樹脂酸含有量の変 化を Fig.-3 に示す。

樹脂酸含有量の低下は酸価の低 下にほぼ比例しており，反応中の 酸価の低下は主として樹脂酸の分 解に起因しているものと考えられ る。またヨウ素を $0.5 \%$ 使用し $240^{\circ} \mathrm{C}$ で $4 \mathrm{hr}$ 反応させた後の生 成物について不ケン化物の含有量 を測定した結果, $13.1 \%$ であり， 原料トール油に対して $2.9 \%$ の增 加がみられたことから酸価低下の 原因はヨウ素の接触作用による樹 脂酸の脱カルボキシル化によるも のと考えられる。

\section{$3 \cdot 2 \cdot 2$ 不均化反応条件}

触媒添加量, 反応温度, 反応時 間をいろいろかえて反応させたと きのモノェン酸,リノール酸, ア ビエチン酸およびデヒドロアビエ チン酸の含有量を Table-3 に示 す。

ヨウ素使用量 $0.1 \%$ 以下または温度 $200^{\circ} \mathrm{C}$ 以下の条 件では反応は拉そく，トール油の不均化反応条件として は充分でない。アビェチン酸を実質的に 0 とするにはヨ

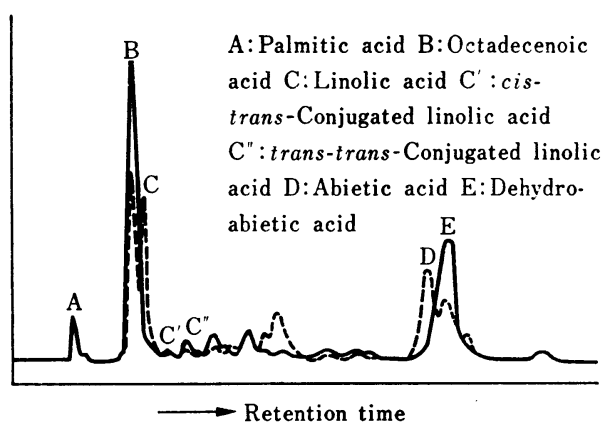

Fig.-1 Gaschromatogram of tall oil (….) and disproportionated tall oil ( $\longrightarrow$ ). 


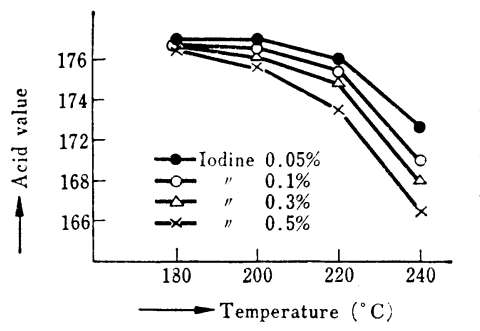

Fig.-2 Acid value of reaction products for $4 \mathrm{hrs}$.

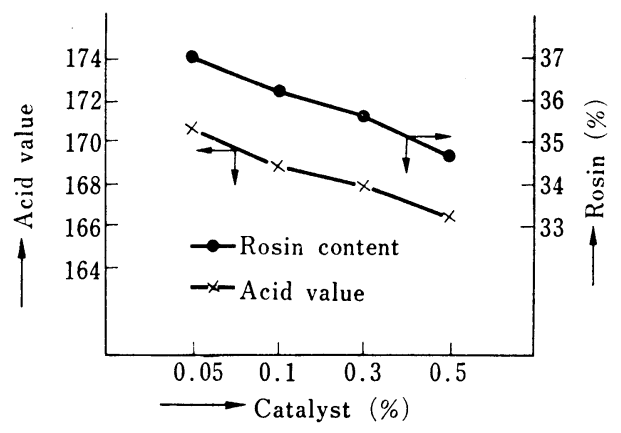

Fig.-3 Relation between acid value or rosin content and catalyst amount used.

Table-3 Result of disproportionation of tall oil with iodine in various condition.

\begin{tabular}{|c|c|c|c|c|c|c|c|c|}
\hline & \multicolumn{3}{|c|}{ Reaction condition } & \multirow[b]{2}{*}{ Pal. } & \multirow[b]{2}{*}{ Oct. } & \multirow[b]{2}{*}{ Lin. } & \multirow[b]{2}{*}{$\mathrm{Ab}$} & \multirow[b]{2}{*}{ Deab. } \\
\hline & $\begin{array}{c}\text { Catalyst } \\
(\%)\end{array}$ & $\begin{array}{l}\text { Temp. } \\
\left({ }^{\circ} \mathrm{C}\right)\end{array}$ & $\begin{array}{c}\text { Time } \\
(\mathrm{hr})\end{array}$ & & & & & \\
\hline 12 & 0.5 & 240 & $\begin{array}{l}0.5 \\
1 \\
2 \\
4\end{array}$ & $\begin{array}{l}3.8 \\
" \prime \\
" 1\end{array}$ & $\begin{array}{l}33.5 \\
36.6 \\
38.5 \\
38.6\end{array}$ & $\begin{array}{l}0 \\
0 \\
0 \\
0\end{array}$ & $\begin{array}{l}0 \\
0 \\
0 \\
0\end{array}$ & $\begin{array}{l}17.0 \\
17.6 \\
18.4 \\
19.5\end{array}$ \\
\hline I3 & 0.5 & 220 & $\begin{array}{l}0.5 \\
1 \\
2 \\
4\end{array}$ & $\begin{array}{l}" 1 \\
" 1 \\
"\end{array}$ & $\begin{array}{l}27.2 \\
31.0 \\
33.1 \\
36.0\end{array}$ & $\begin{array}{l}4.7 \\
1.6 \\
0 \\
0\end{array}$ & $\begin{array}{l}0 \\
0 \\
0 \\
0\end{array}$ & $\begin{array}{l}14.5 \\
15.9 \\
17.4 \\
20.8\end{array}$ \\
\hline 14 & 0.5 & 200 & $\begin{array}{l}0.5 \\
1 \\
2 \\
4\end{array}$ & $\begin{array}{l}" \prime \\
" \prime \\
" \prime\end{array}$ & $\begin{array}{l}23.5 \\
25.7 \\
26.7 \\
28.5\end{array}$ & $\begin{array}{r}12.9 \\
11.3 \\
8.4 \\
3.8\end{array}$ & $\begin{array}{l}6.7 \\
4.2 \\
1.5 \\
0\end{array}$ & $\begin{array}{l}14.1 \\
15.1 \\
17.3 \\
21.8\end{array}$ \\
\hline 15 & 0.5 & 180 & 4 & " & 26.2 & 3.9 & 3.8 & 15.2 \\
\hline 16 & 0.3 & 240 & $\begin{array}{l}0.5 \\
1 \\
2 \\
4\end{array}$ & $\begin{array}{l}\prime \prime \\
" 1 \\
" 1\end{array}$ & $\begin{array}{l}26.5 \\
28.3 \\
30.3 \\
32.5\end{array}$ & $\begin{array}{l}6.5 \\
0 \\
0 \\
0\end{array}$ & $\begin{array}{l}0.9 \\
0 \\
0 \\
0\end{array}$ & $\begin{array}{l}12.9 \\
16.0 \\
17.5 \\
18.6\end{array}$ \\
\hline 17 & 0.3 & 220 & $\begin{array}{l}0.5 \\
1 \\
2 \\
4\end{array}$ & $\begin{array}{l}\prime \prime \\
" 1 \\
" 1\end{array}$ & $\begin{array}{l}23.5 \\
25.4 \\
27.5 \\
30.1\end{array}$ & $\begin{array}{r}10.8 \\
7.6 \\
2.5 \\
1.1\end{array}$ & $\begin{array}{l}4.8 \\
2.3 \\
0 \\
0\end{array}$ & $\begin{array}{l}13.9 \\
16.3 \\
17.8 \\
19.2\end{array}$ \\
\hline 18 & 0.3 & 200 & $\begin{array}{l}0.5 \\
1 \\
2 \\
4\end{array}$ & $\begin{array}{l}\prime \prime \\
" \\
"\end{array}$ & $\begin{array}{l}23.5 \\
24.8 \\
25.5 \\
26.6\end{array}$ & $\begin{array}{r}14.7 \\
13.0 \\
11.4 \\
8.2\end{array}$ & $\begin{array}{r}11.4 \\
9.5 \\
5.8 \\
4.7\end{array}$ & $\begin{array}{r}8.1 \\
8.4 \\
8.6 \\
11.9\end{array}$ \\
\hline 19 & 0.3 & 180 & 4 & $"$ & 25.8 & 9.9 & 6.7 & 8.4 \\
\hline 20 & 0.1 & 240 & 4 & " & 26.9 & 8.2 & 3.8 & 12.1 \\
\hline 21 & 0.1 & 220 & 4 & $"$ & 25.3 & 10.6 & 4.0 & 10.6 \\
\hline 22 & 0.1 & 200 & 4 & $"$ & 24.6 & 14.0 & 8.7 & 8.4 \\
\hline 23 & 0.1 & 180 & 4 & $"$ & 24.4 & 14.9 & 13.1 & 8.0 \\
\hline 24 & 0.05 & 240 & 4 & " & 24.6 & 15.3 & 3.5 & 10.6 \\
\hline 25 & 0.05 & 220 & 4 & " & 24.5 & 15.2 & 8.1 & 10.0 \\
\hline 26 & 0.05 & 200 & 4 & " & 23.9 & 15.1 & 13.0 & 9.2 \\
\hline 27 & 0.05 & 180 & 4 & " & 23.9 & 15.1 & 13.6 & 9.0 \\
\hline
\end{tabular}

Pal. Palmitic acid, Oct. Octadecenoic acid, Lin. Linolic acid Ab. Abietic acid, Deab. Dehydroabietic acid

18

ウ素 $0.3 \%, 220^{\circ} \mathrm{C}$ 以上の 条件が，またリノール酸を 実質的に 0 とするにはヨウ 素 $0.3 \%, 240^{\circ} \mathrm{C}$ 以上また はヨウ素 $0.5 \%, 220^{\circ} \mathrm{C}$ 以 上の条件が必要である。

触媒使用量および反応温 度とオクタデセン酸生成量 との関係を Fig.-4 に, デ ヒドロアビエチン酸生成 量との関係を Fig.-5 に示 す。

オクタデセン酸については触媒 量が多いほどまた温度が高いほど その生成量は増加しているが，デ ヒドロアビェチン酸についてはヨ ウ素 $0.5 \%$ では $200^{\circ} \mathrm{C}$ で，ヨウ 素 $0.3 \%$ では $220^{\circ} \mathrm{C}$ で極大を示 しており，それ以上の温度ではむ しろ減少している。これはすでに $200^{\circ} \mathrm{C}$ 付近より樹脂酸の脱カルボ キシル化が起こっている事在示し ている。

ヨウ素添加量 $0.5 \%$, 反応温度 $220^{\circ} \mathrm{C}$ について各成分含有率の時 間的変化变 Fig.-6 示す。

トール油に少量 (1.0\%) 存在 するステアリン酸の含有量は反応 中ほ上んど変化していない。また 反応初期に共役リノール酸の生成 が認められ，0.5 hr 後に cis-trans 共役リノール酸 $3.8 \%$, transtrans 共役リノール酸 $5.8 \%$ の 極大值を示したのち徐々に減少し ている。こ机は灌田ら がリノー ル酸メチルとヨウ化水素の反応で 指摘しているようにリノール酸か らのモノエン酸の生成は共役リノ 一ル酸を中間体として進んでいる ことを示すものと考える。窪田 ら ${ }^{10)}$ はサフラワー油をヨウ素 $3 \%, 200^{\circ} \mathrm{C}$ で $2 \mathrm{hr}$ 反応させると 脂肪酸の分解生成物とともにオク タデセン酸が生成することを報告 して打り，その分解生成物中にア ルキルベンゼン誘導体の存在を認 め, こ机が水素供給源であろうと 推定しているがオクタデセン酸の 


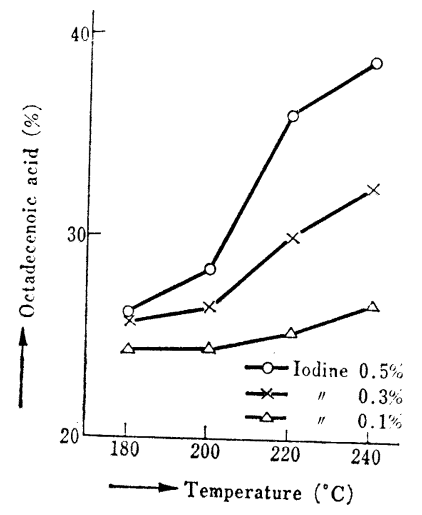

Fig. -4 Effect of temperature on yield of octaciecenoic acid.

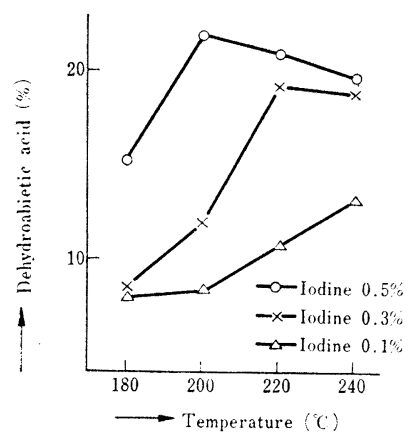

Fig.-5 Effect of temperature on yield of dehydroabietic acid.

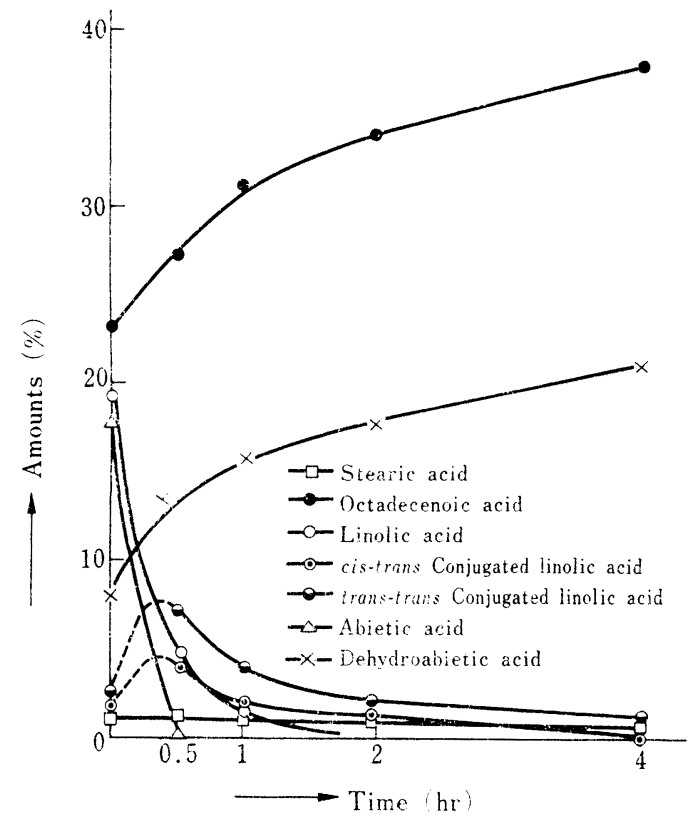

Fig. -5 Changes of components during disproportionation with $0.5 \%$ icdine at $220^{\circ} \mathrm{C}$.

収率についてはふれていない。本実験ではヨウ素 $0.5 \%$, $220^{\circ} \mathrm{C}, 4 \mathrm{hr}$ の条件でオクタデセン酸の収率 64.89 , 一 方アビエチン酸よりデヒドロアビエチン酸の収率 7.2.2 它であり，リノール酸よりもアビエチン酸の方が良好 な水絜供給源となりオクタデセン酸の収率が间上してい るもの上考えられる。ま化応中ステアリン酸の念有珪 は実質!変化して却らずリノ一ル酸からオクタデセン酸 一の水素付加のみが選択的に起こっている。

このこしはリノール酸の孤立二重結合への直接水菜付 加でなく共役ジェン酸を中間体上しそれに水素付加况起 こっていることを支持する。

\section{$3 \cdot 3$ 生成モノエン酸の構造}

ヨウ素 $0.5 \%, 220^{\circ} \mathrm{C}, 4 \mathrm{hr}$ 反応したものに ついて, 脂肪酸中の trans 異性体の含有率を測 定した結果 $38.9 \%$ であった。別に GLCによ り求めたオクタデセン酸の含有率は $88 \%$ であ ったのでオクタデセン酸中の trans 体の含有 率は $45 \%$ となり，リノール酸より生成した才 クタデセン酸だけでなく，トール油に含まれて いたオレイン酸の trans 化も一部おこってい ることを示す。

同一試料について二重結合の分布を測定した 結果を Fig.-7 に示す。

C 9 位に二重結合を有するモノエン酸が 36.4 \% 存在するほかは二重結合は C 5-C 14 に広く 分布しており，先に述べたりノール酸からのモ ノエン酸の生成が共役ジェンを経由しているこ とを支持する。

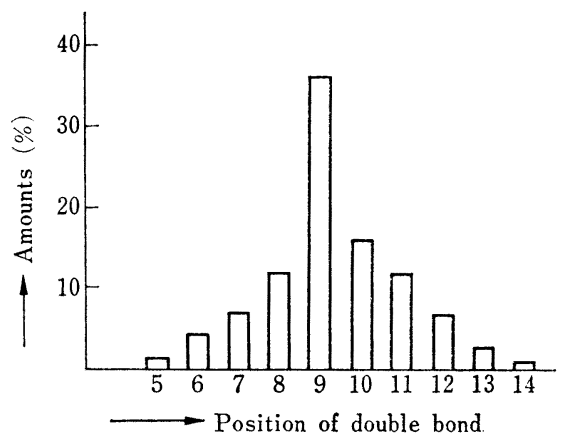

Fig.-7 Distribution of double bond in the octadecenoic acid obtained by disproportionation of tall oil with $0.5 \%$ iodine at $220^{\circ} \mathrm{C}$ for $4 \mathrm{hrs}$.

以上トール油の不均化反応においてはヨウ素がきわめ て有効な触媒であることおよびその反応条件としてはヨ ウ素 $0.5 \%$, 温度 $220^{\circ} \sim 240^{\circ} \mathrm{C}, 4 \mathrm{hr}$ が適当であること を明らかにした。

また反応初期において共役りノール酸ぶ一たん極大值 を示した後徐々に減少しているこ上，リノール酸への水 素付加が撰択的におこりオレイン酸への水素付加が事実 上ほとんど認められないこと，および生成モ（エン酸の 二重結合が C 5 C 14 に広く分布していることなどか らモノエン酸の生成は共役リノ一ル酸圭中間体として進 行しているものと推定した。

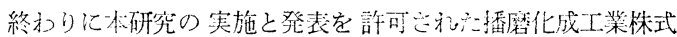
会社社長長郤川末占氏ならびに中央研究所琶考林他家男氏なよ び本研究の発表にあたり終始御指導御鞭達をいただいた大阪大 学工学部小森三郎教授, 岡原光男助教授ならざに池用功氏に 梁く感謝いし安与。

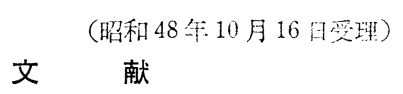

1) J.W. Nilson, Ind. Eng. Chem., 40, 530, (1948); 
R.F. Dunbrook, Ind. Rubber World, 117, 203(1947)

2) J.T. Hays et al., Ind. Eng. Chem. 39, 1129 (1947); J.L. Azorlosa, Ind. Eng. Chem., 41, 1626 (1949)

3) Don E. Floyd, (General Mills Inc.) U.S. 2,617,792 (1952)

4) R.C. Palmer, (Heyden Newport Chemical Corp.) U.S. 2,794,017 (1957)

5) Torsten Hasselstrom, ( $\mathrm{G} \&$ A Laboratories) U.S.
2,311,386 (1943)

6) P.D. Partrick, (Westvaco Corporation) U.S. 3,528, 959 (1970)

7) Report of the Spectroscopy Commitee, J. Amer. Oil. Chem. Soc., 36, 627 (1959)

8) 椎多, 油化学, 19, 154 (1970)

9）滥田, 第, 10 回油化学研究発表会, 17, A-12 (1971)

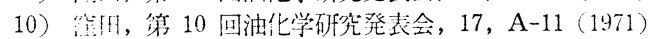

